\title{
Przedmiot zobowiązania z umowy o twórczość naukową
}

\section{Wprowadzenie}

mmanentną cechą pracy o charakterze twórczym jest jej faktyczny charakter. Praca twórcza jest połączeniem konkretnych czynności realnych z pracą umysłową i zazwyczaj stanowi zbiór działań o charakterze rutynowym i twórczym. Jej zwieńczeniem jest powstanie utworu prawa autorskiego - dobra prawnie chronionego, które z mocy samego prawa w momencie jego ustalenia, staje się przedmiotem prawa. Stosunek prawny wykreowany umową o wykonywanie pracy twórczej jest dość złożony. W pojęciu twórczości można bowiem rozróżnić jej dwa podstawowe znaczenia: czynnościowe i przedmiotowe. W tym pierwszym znaczeniu stanowi ona wykonywanie oznaczonych aktów realnych o charakterze twórczym. Czynności mogą być dokonywane na rzecz innej osoby na podstawie umowy cywilnoprawnej, której przedmiotem jest świadczenie usług, bądź na podstawie umowy pracowniczej i wówczas mówimy o dobrowolnym, odpłatnym, podporządkowanym i osobistym świadczeniu rodzajowo określonej pracy na warunkach pracowniczych. W znaczeniu przedmiotowym, $\mathrm{z}$ uwagi na powstanie autorskich praw osobistych i majątkowych do efektu tej pracy, pojęciu twórczości towarzyszą zagadnienia ochrony praw do utworu powstałego w wyniku wykonywania obowiązków umownych oraz podmiotu uprawnionego $\mathrm{z}$ tytułu praw autorskich osobistych i majątkowych ${ }^{1}$. W fazie wykonywania umowy sytuacja prawna twórcy - pracownika lub wykonawcy

\footnotetext{
* Dr Joanna Szyjewska-Bagińska - doktor nauk prawnych, Wyższa Szkoła Administracji Publicznej w Szczecinie, Wydział Administracji i Nauk Społecznych, adiunkt.

${ }^{1}$ Podobna wieloznaczność terminologiczna dotyczy pojęcia „pracy badawczej”, która może mieć znaczenie czynnościowe i przedmiotowe. Inne jest znaczenie tego terminu w zależności od tego, czy oznacza czynności ludzkie, czy też efekt tych czynności. Zob. A. Niewęgłowski, Wyniki prac badawczych w obrocie cywilnoprawnym, Warszawa 2010, s. 30-31.
} 
innej umowy zobowiązującej do wykonania oznaczonej pracy, jest regulowana przepisami prawa pracy lub prawa zobowiązań. Natomiast ocena uprawnień i obowiązków stron umowy dotyczących korzystania z efektów pracy twórczej podlega przepisom prawa autorskiego. Stosunek prawny zaistniały w wyniku zawarcia umowy o wykonywanie pracy twórczej podlega zatem regulacji prawa pracy lub prawa cywilnego oraz, pozostającymi do nich w relacji komplementarności, przepisami prawa autorskiego ${ }^{2}$.

W przypadku gdy przedmiotem umowy jest twórczość zastosowanie znajdą zarówno przepisy dotyczące umów o świadczenie usług, czyli wykonywania oznaczonej pracy realnej ${ }^{3} \mathrm{o}$ charakterze twórczym, jak i w przepisy regulujące umowne dysponowanie prawami autorskimi do utworu. Podział ten zdaje się być wyraźnie dostrzegalny przy zawieraniu umowy cywilnoprawnej, której efektem jest powstanie utworu prawa autorskiego. W takiej umowie konieczne jest bowiem rozróżnienie uzgodnień umownych dotyczących zobowiązania wykonawcy do wykonania egzemplarza utworu lub stworzenia utworu niemającego materialnego nośnika oraz zobowiązania wykonawcy (twórcy) do przeniesienia autorskich praw majątkowych lub udzielenia zezwolenia na korzystanie $\mathrm{z}$ utworu. W przypadku pracowniczego zatrudnienia twórcy, z uwagi na regulację art. 12 i art. 14 prawa autorskiego, podstawą obowiązku wykonania oznaczonej pracy oraz nabycia praw autorskich lub innych uprawnień do korzystania $\mathrm{z}$ utworu jest sama umowa o pracę 4 . Wynagrodzenie wypłacane pracownikowi ze stosunku pracy obejmuje gratyfikację z tytułu wykonywania pracy, jak i z tytułu nabycia przez pracodawcę oznaczonych uprawnień do utworu ${ }^{5}$. Przy umownym wyko-

${ }^{2}$ T. Kuczyński, Twórczość autorska i wynalazcza jako kategoria prawa pracy. Wybrane zagadnienia, PiZS 1998, nr 3, s. 11-12.

${ }^{3} \mathrm{~W}$ doktrynie prawa cywilnego podkreślono, że terminem „usługa” nie określa się wszystkich, objętych umowami typowymi, zachowań. Kodeks cywilny nie uważa za usługę świadczeń polegających na zapłacie ceny albo wynagrodzenia, a także świadczeń, których treścią jest przeniesienie praw albo oddanie rzeczy lub praw w czasowe używanie innej osobie. L. Ogiegło, Pojęcie usługi i umów o świadczenie usług w ujęciu kodeksu cywilnego, SIS 1979, t. V, s.140.

${ }^{4}$ Każda czynność prawna wywołuje nie tylko skutki w niej wyrażone, lecz również te, które wynikają m.in. z przepisów ustawy (art. 56 kodeksu cywilnego). $Z$ uwagi na regulację art. 12 prawa autorskiego, podstawą nabycia przez pracodawcę autorskich praw majątkowych w granicach wynikających z celu umowy o pracę i zgodnego zamiaru stron jest umowa o pracę, nawet wtedy gdy sama umowa o prace nie zawiera postanowień dotyczących praw autorskich. W przypadku zatrudniania twórcy przez instytucję naukową, na podstawie art. 14 PrAut nabywa ona prawo do pierwszeństwa opublikowania utworu naukowego pracownika, korzystania z materiału naukowego zawartego w utworze, oraz udostępniania utworu osobom trzecim, jeżeli to wynika $\mathrm{z}$ uzgodnionego przeznaczenia utworu.

${ }^{5}$ Pojęcie wynagrodzenia za pracę nie zostało zdefiniowane w przepisach prawa pracy, dlatego w doktrynie wskazuje się na trudności z zakwalifikowaniem określonych świadczeń wypłacanych pracownikowi do wynagrodzenia za pracę będącego świadczeniem należnym za pracę wykonaną, lub do innych należności ze stosunku pracy, mających funkcję alimentacyjną. M. Nowak, Wynagrodzenie za prace, Warszawa 2014, s. 11-13, 21-44; wynagrodzenie za pracę na gruncie prawa pracy zostaje 
nywaniu pracy twórczej, której efektem jest powstanie utworu prawa autorskiego, wynagrodzenie wypłacane twórcy co do zasady, jest świadczeniem wzajemnym zarówno za wykonane czynności, jak i za uzyskane prawa autorskie do utworu lub udzieloną licencję. Przy utworach pracowniczych wynika to $\mathrm{z}$ art. 12 prawa autorskiego, natomiast przy zawieraniu umowy cywilnoprawnej stronom przysługuje swoboda ustalenia jaka część wynagrodzenia stanowi zapłatę za wykonanie czynności, a jaka część za dysponowanie prawami autorskimi do utworu.

Inaczej będzie wyglądała sytuacja gdy przedmiotem umowy jest twórczość naukowa, w tym dydaktyczna. Wspomniana odmienność dotyczy zarówno pracowniczego zatrudniania twórcy przez instytucję naukową, jak i wykonywania twórczości naukowej i dydaktycznej na podstawie umowy obligacyjnej. W przypadku pracowniczego zatrudnienia twórcy przez instytucję naukową, zastosowanie ma regulacja ustawowa wynikająca $\mathrm{z}$ art. 14 PrAut $^{6}$, która wyłącza stosowanie zasad ogólnych. Przy tworzeniu utworów naukowo-dydaktycznych na podstawie umowy cywilnoprawnej, należy natomiast mieć na względzie specyfikę pracy o charakterze naukowo-dydaktycznym. Struktura świadczenia umownego wynikającego z zawarcia umowy dotyczącej twórczości naukowo-dydaktycznej, wskazuje, że przedmiotem takiej umowy w większym zakresie jest twórczość w znaczeniu czynnościowym. To z kolei oznacza, że wynagrodzenie umowne twórców będzie stanowiło w większej części zapłatę za wykonywanie czynności faktycznych, będących równocześnie czynnościami twórczymi, aniżeli za dysponowanie prawami autorskimi do utworów naukowych.

\section{Zasady ogólne wykonywania pracy twórczej}

Praca twórcza może być wykonywana na podstawie stosunku pracy lub innej umowy cywilnoprawnej ${ }^{7}$. Wybór przez strony oznaczonej formy zatrudnienia ma daleko idące konsekwencje dotyczące prawa korzystania z efektów tej pracy, czyli utworów prawa autorskiego. Każdy z typów zatrudnienia ma bowiem swoje

oderwane od rynkowej wartości wykonywanej pracy i staje się wynagrodzeniem przysługującym $\mathrm{z}$ tytułu samego faktu zatrudnienia. K. Bomba, Od wynagrodzenia za pracę do wynagrodzenia z tytułu zatrudnienia - kilka uwag na temat ewolucji pojęcia wynagrodzenia za pracę, [w:]40 lat Kodeksu pracy, red. Z. Góral, M. Mielczarek, Warszawa 2015, s. 216.

${ }^{6}$ Ustawa z dnia 4 lutego 1994 r. o prawie autorskim i prawach pokrewnych (Dz. U. z 2017 r., poz. 880 ze zm.).

7 Poza zakresem niniejszego opracowania pozostawiono pracę twórczą wykonywaną przez doktorantów, a to $\mathrm{z}$ tego powodu, że świadczenie twórczej pracy odbywa się w ramach stosunku administracyjnoprawnego, jaki łączy uczestnika studiów doktoranckich i uczelnię. A. Musiała, [w:] Akademickie prawo pracy, komentarz do art. 107-158 oraz 196-201a i 226 ustawy - Prawo o szkolnictwie wyższym, red. K.W. Baran, Warszawa 2015, s. 365; M. Skąpski, Charakter prawny studiów doktoranckich, PiP 1998, nr 2, s. 70. 
odrębne uregulowania prawne. Konsekwencją pracowniczego zatrudniania twórcy jest nabycie przez pracodawcę autorskich praw majątkowych do utworu $\mathrm{w}$ granicach wynikających $\mathrm{z}$ celu umowy o pracę i zgodnego zamiaru stron. Zgodnie $\mathrm{z}$ art. 12 PrAut skutek prawny w postaci przejścia praw na pracodawcę (cessio legis) powstaje w momencie złożenia przez pracodawcę oświadczenia woli o przyjęciu utworu. W przypadku gdy oświadczenie pracodawcy dotyczące przyjęcia utworu lub uzależnieniu jego przyjęcia od dokonania określonych zmian nie zostało złożone, choćby w sposób dorozumiany, po upływie sześciu miesięcy od dostarczenia utworu, stosownie do art. 13 PrAut, uważa się, że utwór został przyjęty bez zastrzeżeń. W tej samej chwili dochodzi do przejścia autorskich praw majątkowych $\mathrm{z}$ pracownika na pracodawcę. Wynagrodzenie za pracę wypłacone pracownikowi jest rekompensatą zarówno za świadczenie pracy o charakterze twórczym, jak i za nabyte przez pracodawcę prawa do utworu pracowniczego.

Zawarcie z twórcą umowy o charakterze cywilnoprawnym poddaje ten stosunek prawny pod regulację zarówno prawa cywilnego, jak i ustawy o prawie autorskim i prawach pokrewnych. Cywilnoprawną podstawą świadczenia pracy przez twórcę może być umowa o dzieło lub umowa o świadczenie usług, która o ile nie jest uregulowana innymi przepisami, to na mocy art. $750 \mathrm{kc}$ stosuje się do niej odpowiednio przepisy o zleceniu. Inne umowy nazwane o świadczenie usług, takie jak: umowa agencyjna czy umowa o roboty budowlane raczej nie znajdują zastosowania do wykonywania pracy o charakterze twórczym. Z uwagi na to, że rezultatem pracy twórczej jest powstawanie wytworów chronionych prawem autorskim, umowa cywilnoprawna powinna być uzupełniona o regulacje odnoszące się do praw autorskich do utworu. W umowie strony mogą zawrzeć postanowienie o przeniesieniu na zamawiającego autorskich praw majątkowych na oznaczonych w umowie polach eksploatacji lub o udzieleniu licencji na korzystanie z utworu powstałego w wyniku wykonywania obowiązków umownych. Wynagrodzenie należne twórcy na podstawie takiej „mieszanej” umowy jest wówczas świadczeniem wzajemnym za wykonywanie czynności twórczych (świadczenie pracy, wykonywanie oznaczonych usług lub dzieła) oraz za przeniesienie praw autorskich lub udzielenie licencji. Wydaje się, że strony powinny w umowie doprecyzować, że należne twórcy wynagrodzenie jest wynagrodzeniem za wykonanie (świadczenie) pracy i przeniesienie praw autorskich lub udzielenie licencji, z uwagi na to, że zarówno umowa o dzieło (art. 627 kc), umowa zlecenia (art. $735 \$ 1 \mathrm{kc}$ ) jak i umowa o przeniesienie autorskich praw majątkowych i umowa licencyjna (art. 43 PrAut) zostały ustawowo ukształtowane jako umowy odpłatne. Stronom umowy przysługuje dość duży zakres swobody w ustalaniu podstaw prawnych wynagrodzenia twórcy i decydowania jaka część wynagrodzenia umownego należnego twórcy za wykonanie umowy stanowi wynagrodzenie za świadczenie pracy, a jaka jego część jest zapłatą za 
dokonanie czynności prawnej - rozporządzenie prawami autorskimi do utworu lub udzielenie licencji.

\section{Regulacja szczególna dotycząca pracowniczych utworów naukowych}

Przywołane powyżej zasady ogólne, dotyczące umownych podstaw wykonywania pracy twórczej i wypłacanego twórcy wynagrodzenia przedstawiają się odmiennie w przypadku pracowniczego zatrudnienia twórcy przez instytucję naukową. Kształt pracowniczego stosunku prawnego istniejącego pomiędzy instytucją naukową a twórcą (naukowcem - pracownikiem) wynika $\mathrm{z}$ regulacji szczególnej zawartej ustawie o prawie autorskim i prawach pokrewnych. Zgodnie $\mathrm{z}$ art. 14 PrAut ust. 1. Jeżeli w umowie o pracę nie postanowiono inaczej, instytucji naukowej przysługuje pierwszeństwo opublikowania utworu naukowego pracownika, który stworzył ten utwór w wyniku wykonywania obowiązków ze stosunku pracy. Twórcy przysługuje prawo do wynagrodzenia. Pierwszeństwo opublikowania wygasa, jeżeli w ciagu sześciu miesięcy od dostarczenia utworu nie zawarto z twórca umowy o wydanie utworu albo jeżeli w okresie dwóch lat od daty jego przyjęcia utwór nie został opublikowany. Ustęp 2 stanowi, instytucja naukowa może, bez odrębnego wynagrodzenia, korzystać z materiału naukowego zawartego $w$ utworze, o którym mowa $w$ ust. 1 , oraz udostepniać ten utwór osobom trzecim, jeżeli to wynika z uzgodnionego przeznaczenia utworu lub zostało postanowione w umowie.

Przytoczony przepis budzi w doktrynie szereg wątpliwości. Po pierwsze, istnieją rozbieżności dotyczące zakresu przedmiotowego pojęcia „utworu naukowego", a dokładnie czy w zakres tego pojęcia należy włączyć również utwory tworzone przez pracowników lecz służące jedynie celom dydaktycznym, m.in. podręczniki i skrypty ${ }^{8}$. Nie do końca jasny jest również zakres podmiotowy art. 14 PrAut, z uwagi na użycie przez ustawodawcę zwrotu „umowa o pracę",

${ }^{8}$ Za szerokim rozumieniem pojęcia utworu naukowego, obejmującym także dzieła syntetycznie odtwarzające stan wiedzy na określonym obszarze np. podręczniki, materiały edukacyjne, skrypty oraz prezentacje opowiedzieli się: J. Błeszyński, Prawo autorskie, Warszawa 1985, s. 91; D. Flisak, [w:] Prawo autorskie i prawa pokrewne, Komentarz LEX, red, D. Flisak, Warszawa 2015, s. 205; M. Poźniak-Niedzielska, G. Tylec, Działalność naukowo-dydaktyczna na wyższej uczelni w świetle prawa autorskiego, $\mathrm{PiP}$ 5/2009, s. 36; A. Szewc, Dzieła naukowe $i$ ich status $w$ prawie autorskim, PiP 1997 r., nr 10, s. 23-26 Inni autorzy wskazują na konieczność odróżnienia utworu naukowego od utworu dydaktycznego, T. Bakalarz, Twórczość pracowników naukowych. Regulacja prawna. Warszawa 2015, s. 147-148;E. Czarny-Drożdzejko, Wybrane zagadnienia z zakresu prawa autorskiego w prawie o szkolnictwie wyższym, Przegląd Sądowy, wrzesień 2016, s. 92. P. Stec, wskazuje, że wyłączenie zastosowania art. 14 do podręczników czy innych materiałów dydaktycznych mogłaby być korzystne dla twórców. Oznaczałoby to przejście na zasady ogólne, w konsekwencji instytucja naukowa nabywałaby prawa do nich w zakresie wynikającym $\mathrm{z}$ celu umowy o prace i zgodnego zamiaru stron. P. Stec, Uczelnia jako podmiot praw na dobrach niematerialnych, PiP 1/2008, s. 57. 
w sytuacji gdy znaczna część pracowników naukowych wykonuje pracę w oparciu o stosunek mianowania9. Kolejną wątpliwość wzbudza zakres uprawnienia pracodawcy - instytucji naukowej, ustawowo określony jako „pierwszeństwo opublikowania"10i charakter prawny umowy o wydanie utworu ${ }^{11}$ zawieranej pomiędzy instytucją naukową a pracownikiem. Czwartą kwestią wzbudzająca spore kontrowersje jest ustalenie znaczenia ustawowego zwrotu „korzystania

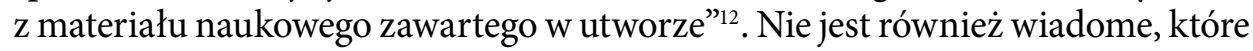

${ }^{9}$ Na gruncie prawa pracy umowa o pracę jest jednym z kilku sposobów nawiązania stosunku pracy. Stosunek pracy między instytucja naukowa a pracownikiem może być nawiązany również w drodze mianowania. W doktrynie przyjmuje się, że wbrew użytemu w art. 14 PrAut pojęciu „umowa o pracę”, należy objąć jego zakresem również pracowników mianowanych. W chwili tworzenia ustawy o prawie autorskim pracownicy naukowi byli zatrudniani głównie na podstawie mianowania. M. Bieganowska, Ochrona autorsko prawna pracowniczych utworów naukowych, PUG 1998 r., nr 11, s. 23; T. Bakalarz, Twórczość pracowników, s. 185-187 tenże, Twórczość naukowa pracowników, PS 2010, nr 10, s. 40-42; J. Barta, R. Markiewicz, Prawo autorskie, Warszawa 2016, s. 115; Za literalnym i wąskim rozumieniem pojęcia „umowa o pracę" zawartym w art. 12 ustawy opowiada się L. Jaworski, Podstawa prawna świadczenia twórczości przez pracownika $w$ świetle art 12 PrAut. MP 6/2005r, s. 295.

${ }^{10} \mathrm{~W}$ starszej doktrynie wskazywano, że uprawnienie pracodawcy - instytucji naukowej skuteczne o charakterze bezwzględnym (skuteczne erga omnes), wykazuje podobieństwo do obciążenia prawa podmiotowego (koncepcja obciążenia autorskich praw ograniczonych, analogiczna do praw rzeczowych). Zob. A. Szewc, Dzieła naukowe, s. 30; Podkreśla się również literalne rozumienie „publikacji”, do którego konieczne jest zaistnienie egzemplarza utworu. Wówczas poza zakresem prawa będzie jego wykorzystanie, na innym aniżeli utrwalenie w postaci przedmiotu materialnego, polu eksploatacji np. prezentacja utworu naukowego $\mathrm{w}$ formie odczytu, wyświetlenia, czy rozpowszechnienia w sieci Internetu w postaci e-booka. Zob. T. Bakalarz, Twórczość naukowa s. 45; K. Kędzierska-Cieślak, Pierwszeństwo instytucji naukowej do opublikowania utworu jej pracownika, PIP 1996, z 8-9, s. 83; E. Czarny-Drożdzejko zwraca jednak uwagę, że pojęcie egzemplarza odnosi się także do formy zapisu na płycie w postaci audiobooka. E. Czarny-Drożdzejko, Wybrane zagadnienia, s. 91.

${ }^{11} \mathrm{Z}$ uwagi na to, że uprawnienia instytucji naukowej powstają ex lege uważa się, że postanowienia umowy powinny zawierać zasady wynagrodzenia twórcy. Zawarcie umowy nie jest jednak konieczne dla skonsumowania przez pracodawcę prawa do pierwszej publikacji utworu. P. Podrecki, Model ochrony praw własności intelektualnej w szkołach wyższych i instytucjach naukowo-badawczych oparty na przepisach prawa autorskiego, [w:] Europejskie regulacje $w$ dziedzinie własności przemysłowejnowe wyzwania, red. A. Adamczyk, Wynalazczość i ochrona własności intelektualnej, z. 28, Kielce 2004, s. 81;A.Kędzierska-Cieślak, Pierwszeństwo, s. 85;

12 W doktrynie wypowiedziano się za wykładnią zwrotu wskazującą na prawo pracodawcy korzystania $\mathrm{z}$ utworu naukowego, a nie tylko materiału naukowego zawartego w utworze. Wskazuje się trzy argumenty: 1) z logicznego punktu widzenia korzystanie z elementów utworu jest także korzystaniem z utworu, 2) gdyby przyjąć, że przepis ten odnosi się do treści dzieła, stanowiłby on całkowite curiosum na gruncie zasad prawa autorskiego, jako że prawo to chroni formę, a nie zawartość dzieła. Ochronę treści dzieła realizują inne przepisy, w szczególności prawo wynalazcze i patentowe, 3) podstawowym prawem pracodawcy jest prawo korzystania $\mathrm{z}$ wyników pracy pracownika, co wynika z przepisów prawa pracy, $\mathrm{w}$ tym zaś przypadku wynikiem pracy twórczej jest utwór, jako taki, a nie zawarty w nim materiał naukowy. A. Szewc, Wynagrodzenie twórców i wykonawców w prawie autorskim i wynalazczym, Sopot 1999, s. 227-228; J. Barta, R. Markiewicz, [w:]Ustawa o prawie autorskim i prawach pokrewnych, Komentarz wyd V, źródło LEX komentarz do art. 14; W. Machała, Ochrona i eksploatacja utworu naukowego. Zagadnienia wybrane, [w:]Ochrona i zarządzanie 
z utworów pracownika są utworami powstałymi w wyniku wykonywania obowiązków ze stosunku pracy, z uwagi na to, że zakres obowiązków pracownika naukowego $\mathrm{z}$ reguły jest formułowany w sposób dość ogólny i ogranicza się do obowiązku prowadzenia badań i prac rozwojowych ${ }^{13}$.

Zgodność $\mathrm{w}$ doktrynie panuje natomiast co do tego, że regulacja szczególna zawarta w art. 14 PrAut stanowi odstępstwo od zasady ogólnej wyrażonej w art. 12 - nabywania przez pracodawcę praw autorskich do utworów pracowniczych stworzonych przez własnych pracowników. Regulacja szczególna dotycząca autorskich praw majątkowych do pracowniczego utworu naukowego jest dla twórców - pracowników znacznie korzystniejsza, aniżeli wynikająca z zasad ogólnych. Wszak prawa autorskie do utworów naukowych pozostają przy twórcy (pracowniku), natomiast jego pracodawcy (jednostce naukowej) ustawodawca przyznał jedynie trzy uprawnienia: pierwszeństwo publikacji utworu, prawo korzystania $\mathrm{z}$ materiału naukowego zawartego $\mathrm{w}$ utworze oraz udostępniania utworu osobom trzecim ${ }^{14}$.

\section{Regulacje ustawy o prawie autorskim dotyczące pracowniczych utworów naukowych jako źródło prawa pracy}

Regulacja zawarta w art. 14 PrAut ustanawia zasady dotyczące praw i obowiązków pracowników - twórców naukowych oraz ich pracodawców - instytucji naukowych. Chodzi o ustawowe ukształtowanie praw i obowiązków związane z pracowniczymi utworami naukowymi: przyznania pracodawcy - instytucji naukowej oznaczonych uprawnień do utworu naukowego pracownika; obowiązku twórcy - respektowania korzystania przez pracodawcę z utworu naukowego $\mathrm{w}$ granicach wyznaczonych art. 14 oraz przyznania twórcy - pracownikowi prawa do dodatkowego wynagrodzenia za skorzystanie przez instytucję naukową z prawa pierwszeństwa opublikowania utworu naukowego oraz, co najważniejsze, prawa pracownika do pełni autorskich praw majątkowych dotyczących utworów naukowych stworzonych w wyniku wykonywania obowiązków pracowniczych.

własnościq intelektualną $w$ szkołach wyższych $w$ świetle obowiązujących przepisów oraz praktykiwybrane zagadnienia, red. A. Adamczyk, Wynalazczość i ochrona własności intelektualnej, z. 39, Kielce 2015, s. 109; Na konieczność rozróżnienia pojęć „materiału naukowego zawartego w utworze” i „utworu naukowego” zwraca też uwagę E. Czarny-Drożdzejko, Wybrane zagadnienia, s. 95-96.

${ }^{13}$ E. Czarny-Drożdzejko, Wybrane zagadnienia, s. 94; Tę samą wątpliwość zgłosiła w trakcie dyskusji po pierwszym panelu konferencji naukowej „Zasady wynagradzania twórców w świetle prawa autorskiego" w Lublinie 25 maja 2017 r. Pani profesor Beata Giesen; Zdaniem D. Flisaka poza zakresem regulacji art. 14 pozostają tworzone dla zawodowej samorealizacji publikacje o charakterze naukowym. D. Flisak, [w:] Prawo autorskie i prawa pokrewne, Komentarz Lex, red. D. Flisak, Warszawa 2015, s. 205.

${ }^{14} \mathrm{O}$ ile wynika to $\mathrm{z}$ uzgodnionego przeznaczenia utworu lub zostało postanowione w umowie. 
Konsekwencją uznania regulacji art. 14 jako normy wyrażającej prawa i obowiązki pracowników będzie uznanie tego przepisu, mimo jego umiejscowienia $\mathrm{w}$ ustawie o prawie autorskim, za źródło prawa pracy ${ }^{15}$. Zgodnie $\mathrm{z}$ wyraźnym brzmieniem art. $9 \$ 1$ ustawy Kodeks pracy, do prawa pracy zalicza się także przepisy ustaw, innych aniżeli Kodeks pracy, jeżeli określają one prawa i obowiązki pracowników i pracodawców. Każda ustawa regulująca zasadniczo stosunki nienależące do prawa pracy, ale zawierająca przepisy które kształtują prawa i obowiązków pracowników, stanowi materialnoprawne źródło prawa pracy ${ }^{16}$. Źródłem prawa pracy są zatem przepisy zawarte w ustawach i rozporządzeniach o ile dotyczą praw i obowiązków pracowniczych. Uznanie art. 14 PrAut za regulację z zakresu prawa pracy będzie miało oznaczone konsekwencje w procesie jego interpretacji. Przy dokonywaniu wykładni tego przepisu należy bowiem uwzględniać hierarchię źródeł prawa pracy, w tym autonomicznych źródeł prawa pracy oraz zasadę uprzywilejowania pracownika wyrażoną $\mathrm{w}$ art. $18 \mathrm{~K}$.p.

W pierwszej kolejności należy wskazać na istniejące w prawie pracy zróżnicowanie źródeł prawa pracy oraz na ich hierarchię. Obok ustawowych źródeł prawa pracy istnieją bowiem pozaustawowe źródła prawa pracy, zwane autonomicznym prawem pracy. Autonomiczne źródła prawa pracy takie jak: postanowienia układów zbiorowych i inne oparte na ustawie porozumienia zbiorowe, regulaminy i statuty są wydawane samodzielnie przez pracodawcę lub ze związkami zawodowymi i obejmują pracowników jednego zakładu pracy ${ }^{17}$. Przepis art. $9 \mathrm{Kp}$ stanowi podstawę normatywnego charakteru tych norm, uznając je za źródła prawa pracy. Do uznania danego aktu specyficznego za źródło prawa pracy przywołany wyżej przepis wymaga spełniania trzech przesłanek, po pierwsze, wyraźnego wymieniania danego aktu w art. 9 K.p., po drugie, oparcia tego aktu na ustawie oraz po trzecie, określania w nim praw i obowiązków stosunku pracy. Dwie pierwsze przesłanki mają charakter formalny, natomiast trzecia stanowi warunek treściowy ${ }^{18}$. Jako źródło prawa pracy w rozumieniu art. $9 \$ 1 \mathrm{Kp}$ w orzecznictwie zostały uznane m.in. postanowienia statutu wyższej uczeln $\mathrm{i}^{19}$. Warto przeanalizować, czy taka kwalifikacja będzie dotyczyła również postanowień regulaminu zarządzania prawami autorskimi i prawami

${ }^{15}$ Regulacje art. 14 praut jako źródło prawa pracy postrzegają T. Bakalarz, Twórczość, s. 16; E. Czarny-Drożdżejko, Wybrane, s. 90; P. Stec, Uczelnia, s. 57; Zdaniem J. Błeszyńskiego, nieważne będzie postanowienie w umowie o pracę przenoszące na pracodawcę całość autorskich praw majątkowych. Autor nie wyjaśnia jednak czy ów zakaz wywodzi z semiimperatywnych norm prawa pracy, uznając art. 12 i 14 PrAut za źródło prawa pracy. J. Błeszyński, Prawo autorskie do utworów stworzonych przez pracowników w trakcie wykonywania obowiązków pracowniczych, PUG 1998, nr 11, s. 33.

${ }_{16}$ Wyrok SN z 2.12.2010 r., II PK 126/10; wyrok SN z 29.01.2008 r., I PK 196/07.

17 L. Florek, Prawo pracy, Warszawa 2015, s. 23.

18 J. Stelina, [w:] Prawo pracy, red. J. Stelina, Warszawa 2016, s. 67.

19 Wyrok SN z 4.12.2008 r., I PK 155/08; wyrok SN z 20.3.2009 r., II PK 219/08. 
pokrewnymi oraz prawami własności przemysłowej oraz zasad komercjalizacji własnością intelektualną uchwalanych przez senat uczelni wyższej, zwłaszcza że spełniają one wszystkie wymogi konieczne do uznania za autonomiczne źródło prawa pracy, zarówno te formalne, jak i warunek merytoryczny. Po pierwsze, regulamin został wprost wymieniony w art. $9 \$ 1 \mathrm{~K}$.p. jako specyficzne źródło prawa pracy, po drugie, podstawą jego wydania jest art. 86c ust. 1, pkt 1 ustawy z dnia 27 lipca 2005 r. Prawo o szkolnictwie wyższym ${ }^{20}$, zgodnie z którym Senat, a w przypadku uczelni niepublicznej - organ wskazany w statucie, uchwala regulamin zarządzania prawami autorskimi i prawami pokrewnymi oraz prawami własności przemysłowej oraz zasad komercjalizacji. Z przywołanego przepisu wyraźnie wynika, że regulamin winien określać w szczególności „prawa i obowiązki uczelni, pracowników oraz studentów i doktorantów w zakresie ochrony i korzystania z praw autorskich i praw pokrewnych oraz praw własności przemysłowej”, co z kolei oznacza, że spełnia on również warunek merytoryczny, a mianowicie określa prawa i obowiązki stron stosunku pracy: uczelni wyższej i jej pracowników. W myśl tego można stwierdzić, że regulamin stanowi źródło pozaustawowego prawa pracy, w rozumieniu art. 9 k.p. ${ }^{21}$.

Przepis art. $9 \$ 2$ K.p kształtuje hierarchię źródeł prawa pracy, ustanawiając tzw. zasadę korzystności ${ }^{22}$. Mianowicie, postanowienia układów zbiorowych, porozumień zbiorowych oraz regulaminów i statutów nie mogą być mniej korzystne dla pracowników niż przepisy Kodeksu pracy oraz innych ustaw i aktów wykonawczych. Jest to reguła kolizyjna związana z określeniem pierwszeństwa w stosowaniu aktu prawnego ${ }^{23}$. Regulacja pomiędzy poszczególnymi źródłami prawa pracy oparta jest na zasadzie uprzywilejowania pracownika. Zasada korzystności jest traktowana w judykaturze w sposób ścisły, a więc $\mathrm{z}$ uwzględnieniem oceny poszczególnych postanowień zawartych $\mathrm{w}$ akcie prawnym, a nie oceny en bloc całego tego aktu ${ }^{24}$. Nie będą miały mocy prawnej te postanowienia regulaminu zarządzania prawami autorskimi i prawami pokrewnymi oraz prawami własności przemysłowej oraz zasad komercjalizacji własnością intelektualną uchwalone przez senat uczelni wyższej, które przyznają pracodawcy prawa autorskie do utworów naukowych lub zezwalają na korzystanie z utworów naukowych powstałych w wyniku wykonywania obowiązków pracowniczych w szerszym zakresie, aniżeli regulacja ustawowa zawarta $\mathrm{w}$ art.

20 Dz. U. z 2016 r., poz. 1842 ze zm.)

21 J. Piątkowski, Kodeks pracy a ustawa -Prawo o szkolnictwie wyższym, w: Zatrudnienie nauczycieli akademickich, red. W. Sanetra, Warszawa 2015, s. 75.

22 J. Stelina, Prawo, s. 69.

23 J. Stelina, Ocena kodeksu pracy z punktu widzenia wybranych jego regulacji, [w:]40 lat Kodeksu pracy, red. Z. Góral, M. Mielczarek, Warszawa 2015, s. 90.

24 J. Stelina, Prawo s. 69, i przywołane tam orzecznictwo. 
$14 \operatorname{PrAut}^{25}$. Te postanowienia regulaminu, które są mniej korzystne, zostaną automatycznie zastąpione przez odpowiednie regulacje zawarte w art. 14 PrAut, które są dla pracownika bardziej korzystne ${ }^{26}$.

\section{Regulacja art. 14 prawa autorskiego jako względnie obowiązująca}

Zupełnie innym zagadnieniem jest natomiast ocena charakteru prawnego normy prawnej wynikającej z art. 14 PrAut zmierzająca do ustalenia, czy ta regulacja ustawowa ma charakter względnie obowiązujący, bezwzględnie obowiązujący, czy też semidyspozytywny ${ }^{27}$. W doktrynie nie ma co do tego zgodności. Część przedstawicieli uznaje, że art. 14 PrAut stanowi przepis o charakterze dyspozytywnym ${ }^{28}$, część wskazuje na jego semiimperatywny charakter ${ }^{29}$. Zwolennicy tego drugiego stanowiska akcentują okoliczność, że analizowany przepis kształtuje treść stosunku pracy, zaś z art. $18 \mathrm{Kp}$ wynika, że postanowienia umów o pracę czy regulaminów pracy nie mogą być mniej korzystne dla pracowników niż przepisy prawa pracy. Z tego powodu klauzula umowna dająca twórcy utworu naukowego - pracownikowi mniejszy zakres praw, aniżeli wynikający z treści art. 14 PrAut, byłaby nieważna ${ }^{30}$. W ich przekonaniu przepis zawiera ustawowe

${ }_{25}$ To oznacza, że z regulaminu zarządzania prawami autorskimi i prawami pokrewnymi oraz prawami własności przemysłowej oraz zasad komercjalizacji własnością intelektualną nie może wynikać, że autorskie prawa majątkowe do utworu naukowego pracownika instytucji naukowej przysługują pracodawcy - instytucji naukowej. Taka regulacja byłaby mniej korzystna dla pracowników instytucji naukowych, aniżeli wynikająca $\mathrm{z}$ art. 14 PrAut, sprzeczna $\mathrm{z}$ art. $9 \$ 1 \mathrm{Kp}$, zatem nie miałaby mocy prawnej.

${ }^{26}$ Jest to konsekwencja zasady uprzywilejowania pracownika. Unormowanie art. $18 \mathrm{Kp}$ ustanawia pewien szczególny mechanizm działania przepisów prawa pracy w sytuacji niezgodności z tymi przepisami postanowień umów o pracę lub innych aktów kreujących stosunek pracy. Z. Góral, O kodeksowym katalogu zasad indywidualnego prawa pracy, Warszawa 2011, s. 200.

${ }_{27}$ Ten trójpodział norm prawnych jest powszechnie przyjmowany w teorii prawa zob. S. Wronkowska, Podstawowe pojęcia prawa i prawoznawstwa, Poznań 2005, s. 74-75, natomiast w doktrynie prawa pracy wyróżnia się dwa rodzaje norm pośrednich - semidyspozytywne i semiimperatywne. Pierwsze z wymienionych zezwalają adresatom normy na czynienie odstępstw od wynikającej z niej dyspozycji, ale tylko w jednym kierunku - na korzyść pracownika. Natomiast dyspozycja normy semiimperatywnej przewiduje wybór pomiędzy z góry określonymi wariantami zachowania. Autonomia stron jest ograniczona przez narzucenie przez normę ściśle wyznaczonych możliwości. J. Stelina, Prawo, s. 56-57.

${ }^{28}$ A. Nowicka, [w:] System, s. 95; T. Bakalarz, Twórczość pracowników, s. 165; P. Podrecki, Model ochrony praw własności intelektualnej w szkołach wyższych i instytucjach naukowo-badawczych oparty na przepisach prawa autorskiego, [w:]Europejskie regulacje $w$ dziedzinie własności przemysłowejnowe wyzwania, red. A. Adamczyk, Wynalazczość i ochrona własności intelektualnej, z. 28, Kielce 2004, s. 81.

${ }^{29}$ J. Błeszyński, Prawo autorskie, s. 94; E. Czarny-Drożdzejko, Wybrane zagadnienia z zakresu prawa autorskiego w prawie o szkolnictwie wyższym, Przegląd Sądowy, wrzesień 2016, s. 89; P. Stec, Uczelnia, s. 57.

${ }^{30}$ P. Stec, Uczelnia, s. 57; 
minimum ochrony interesów pracownika, dlatego umowna zmiana ustawowych zasad może nastąpić tylko na korzyść pracownika. Zwolennicy stanowiska o dyspozytywnym charakterze art. 14 PrAut podkreślają jego literalne brzmienie wskazujące na możliwość zmiany ustawowych warunków w drodze umowy albo podkreślają samodzielność regulacji dotyczącej utworów pracowniczych ${ }^{31}$.

Chcąc zająć stanowisko w tej kwestii wypada zacząć od przypomnienia, o przyporządkowaniu regulacji zawartej w art. 14 PrAut do źródeł prawa pracy. Uprzedzając dalsze wywody warto podkreślić, że to przyporządkowanie nie wyklucza a priori uznania tego przepisu za zawierającego normę względnie obowiązującą. W doktrynie prawa pracy z zasady uprzywilejowania pracownika wyrażonej w art. $18 \$ 1$ i 2 K.p., wywodzi się domniemanie semidyspozytywności norm prawa pracy. Domniemanie to nakazuje przyjąć, że jeżeli z brzmienia danej normy lub innych ważnych względów nie wynika nic innego, wówczas zgodnie $\mathrm{z}$ zasadą ogólną oceniana norma ma charakter semidyspozytywny ${ }^{32}$. Inny niż semidyspozytywny charakter normy może natomiast wynikać wprost z przepisu lub, wyjątkowo, $\mathrm{z}$ istoty regulowanej przez normę materii ${ }^{33}$. $Z$ taką sytuacja mamy do czynienia, jak się wydaje, przy ocenie normy prawnej zawartej w art. 14 PrAut. Z literalnego brzmienia przepisu wynika możliwość umownej zmiany rozkładu praw i obowiązków dotyczących pracowniczego utworu naukowego, wszak przepis stanowi „jeżeli w umowie o pracę nie postanowiono inaczej”. Stąd można uznać, że zasady nabycia praw autorskich do utworów pracowniczych naukowych, mogą zostać zmienione również na mniej korzystne dla pracownika ${ }^{34}$. Może to nastąpić tylko w drodze indywidualnie negocjowanej umowy

${ }^{31}$ Zmiana ustawowych regulacji może być dokonywana w drodze tzw. klauzuli autonomicznej, oznaczającej zgodne oświadczenie woli stron stosunku pracy. T. Bakalarz, Twórczość, s. 165; T. Targosz przedstawia natomiast pogląd o samodzielności regulacji art. 12 i 14 prawa autorskiego, którą wywodzi m.in. z wykładni systemowej oraz funkcjonalnej ustawy. Autor uważa, że unormowania prawa autorskiego odnoszące się do utworów pracowniczych nie stanowią semiimperatywnych normy prawa pracy, lecz regulacje samodzielne. W przeciwnym bowiem razie sformułowanie przepisów art. 12 i 14 byłoby nielogiczne. Po drugie, omawiane przepisy rozstrzygają pewien konflikt między zasadą prawa autorskiego (prawa powstają na rzecz autora) a zasada prawa pracy (pracodawca nabywa prawa do tego co $\mathrm{w}$ wykonaniu pracy stworzy pracownik). Taka norma nie powinna być wykładana w sposób dający nieuzasadniony „prymat” jednej dziedzinie prawa kosztem drugiej. Dlatego, zdaniem Autora, warunki i zakres nabycia przez pracodawcę praw autorskich do utworów pracowniczych mogą być przez strony modyfikowane zarówno w sposób przyznający więcej praw pracodawcy, jak i pracownikowi oraz określenie warunków i zakresu nabycia winno się dokonywać autonomicznie, z uwzględnieniem charakteru normy art. $12 \mathrm{i}$ art. 14 jako sui generis reguły przyporządkowania praw autorskich w stosunkach pracy. T. Targosz, Prawa pracodawcy do utworów pracowniczych - art. 12 pr. Aut. Jako reguła przyporzadkowania praw autorskich w stosunku pracy, [w:]Spory o własność intelektualna, Księga jubileuszowa dedykowana Profesorom Januszowi Barcie i Ryszardowi Markiewiczowi, red. A. Matlak, S. Stanisławska-Kloc, Warszawa 2013, s. 1287- 1292.

32 J. Stelina, Prawo, s. 57.

${ }^{33}$ J. Stelina, Prawo, s. 57.

${ }^{34}$ Aniżeli minimum ustalone w art. 14 PrAut. 
między pracownikiem a instytucją naukową - pracodawcą. Za dyspozytywnym charakterem normy zawartej $\mathrm{w}$ art. 14 PrAut przemawia również dodatkowy argument. A mianowicie, analizowany przepis przewiduje wyjątek nie tylko od zasad ogólnych przewidzianych w art. 12 PrAut, czyli od zasady nabywania przez pracodawcę autorskich praw do utworu pracowniczego, ale również od podstawowych zasad ogólnych prawa pracy. Zgodnie z definicją stosunku pracy zawartą $\mathrm{w}$ art. $22 \$ 1 \mathrm{~K} . \mathrm{p}$., przez nawiązanie stosunku pracy pracownik zobowiązuje się do wykonywania pracy określonego rodzaju na rzecz pracodawcy i pod jego kierownictwem oraz w miejscu i czasie wyznaczonym przez pracodawcę, a pracodawca - do zatrudniania pracownika za wynagrodzeniem. Wynagrodzenie za pracę jest świadczeniem za pracę wykonaną przez pracownika na rzecz pracodawcy. Pomiędzy tymi świadczeniami istnieje ścisła wzajemność, czyli wynagrodzenie ma być odpowiednikiem świadczonej pracy ${ }^{35}$. Na gruncie prawa pracy, oczywistym jest, że pracodawca nabywa prawa do efektów pracy swojego pracownika $^{36}$. Pracodawca powinien zatem, jak się wydaje, nabyć również inne prawa umożliwiające mu korzystanie z efektów pracy - utworów prawa autorskiego ${ }^{37}$. W tym kontekście regulacja art. 14 PrAut, przyznająca twórcy utworu naukowego całość praw autorskich i ustanawiająca na rzecz jego pracodawcy jedynie trzy uprawnienia, takie jak: pierwszeństwo publikacji utworu, prawo korzystania $\mathrm{z}$ materiału naukowego zawartego $\mathrm{w}$ utworze oraz udostępniania utworu osobom trzecim, stanowi regulację wyjątkową. Trudno zatem uznać, że wyznacza ona ustawowe minimum ochrony interesów pracownika. Warto wskazać również, że w nowszej doktrynie prawa pracy zwraca się uwagę na konieczność modyfikacji koncepcji ochronnej funkcji prawa pracy. Chodzi o stworzenie modelu ochrony pełniejszej, kompleksowej i wielokierunkowej obejmującej wszystkich uczestników rynku pracy w odpowiednim dla nich zakresie, wyważając potrzeby dotyczące sytuacji poszczególnych grup podmiotów. W interesie ogólnym, a nie tylko partykularnym, pracodawcy powinni być w miarę możliwości chronieni przed czynnikami utrudniającymi rozwój działalności ${ }^{38}$. Zapewnienie sprawnego i niezakłóconego działania stosunków pracy

${ }^{35}$ M. Nowak, Wynagrodzenie za pracę, red.Z. Góral, Biblioteka Prawa Pracy, Warszawa 2014, s. 19 i nast.

${ }^{36}$ Prawo pracodawcy do korzystania z wyników pracy pracownika, niejako w zamian za wypłacone mu wynagrodzenie jest wskazywane jako jedno praw pracodawcy. J. Piątkowski, Aksjologiczne i normatywne podstawy prawa stosunku pracy, Toruń 2013, s. 216.

${ }^{37}$ Strony umowy o pracę musiały przynajmniej w dorozumiany sposób zezwolić pracodawcy na eksploatacje utworów pracowniczych w zakresie jego dzielności. Na gruncie prawa niemieckiego uważa się, że już z istnienia stosunku pracy wynika przyznanie pracodawcy wyłącznego prawa korzystania $\mathrm{z}$ utworu pracowniczego, a w braku jakichkolwiek postanowień dotyczących praw autorskich należy przyjąć konkludentne przyznanie prawa wyłącznego korzystania na rzecz pracodawcy. Zob. T. Targosz, Prawa pracodawcy, s. 1285 i wskazaną tam literaturę.

${ }^{38}$ M. Skąpski, Ochronna funkcja prawa pracy w gospodarce rynkowej, Warszawa 2006, s. 85, s. $456-457$. 
jest uznawane za metafunkcję prawa pracy, wobec której wszystkie inne funkcje, w tym również funkcja ochronna pracownika, mają charakter podrzędny ${ }^{39}$.

$\mathrm{Z}$ tych powodów należy uznać regulację art. 14 PrAut za mającą charakter względnie obowiązujący, co oznacza, że pracodawca i pracownik w drodze umowy mogą zmienić zasady nabywania praw autorskich przez instytucje naukową. Granicą, której przekroczyć nie mogą, pod rygorem bezskuteczności uzgodnień umownych, są przepisy rozdziału 5 PrAut, w tej części w której zawierają normy bezwzględnie obowiązujące.

\section{Ustawowe uprawnienia instytucji naukowej do pracowniczego utworu naukowego}

Analizując pierwsze z uprawnień pracodawcy - instytucji naukowej wyartykułowane w art. 14 ust. 1 PrAut, czyli prawo do pierwszeństwa publikacji utworu naukowego twórcy należy wskazać, że w doktrynie panuje zgodność co do tego, że jest to prawo przysługujące instytucji naukowej z mocy samej ustawy i jest licencją ustawową ustanowioną na rzecz instytucji ${ }^{40}$. Twórca naukowy zachowuje w całości prawa autorskie do utworu naukowego, natomiast jego pracodawca - instytucja naukowa posiada ograniczone czasowo uprawnienie pierwszeństwa opublikowania utworu swojego pracownika. To uprawnienie instytucji naukowej, nazywane ,jednorazowym przywilejem”, jedynie czasowo ogranicza wykonywanie przez twórcę praw autorskich do utworu naukowego ${ }^{41}$. Podstawę prawną pierwszeństwa publikacji stanowi art. 14 ust. 1 PrAut, zatem nie ma potrzeby zawierania dodatkowej umowy z twórcą, której przedmiotem jest przeniesienie na instytucje naukową prawa do pierwszego opublikowania utworu lub udzielenie licencji ${ }^{42}$. Umowa o wydanie utworu powinna natomiast ustalać wysokość i zasady przysługującego twórcy naukowemu wynagrodzenia ${ }^{43}$. Wynagrodzenie przysługujące twórcy jest uznawane za świadczenie odrębne od wynagrodzenia za pracę pracownika naukowego i mające cywilnoprawny charakter $^{44}$. Prawo do wynagrodzenia $\mathrm{z}$ art. 14 ust. 1 PrAut jest powiązane $\mathrm{z}$ faktem twórczości, a nie pozostawania w stosunku pracy, a ponadto zgodnie z literalnym

39 M. Skąpski, Ochronna, s. 102.

${ }^{40}$ P. Stec, Uczelnia, s. 51; A Nowicka [w:]System Prawa Prywatnego, Prawo autorskie, tom 13, red. J. Barta, Warszawa 2017, s. 29 (Legalis);

${ }^{41}$ T. Bakalarz, Twórczość naukowa, s. 45;

${ }^{42}$ A. Nowicka [w:]System, s. 29 (Legalis); A.Kędzierska-Cieślak, Pierwszeństwo, s. 85.

${ }^{43}$ P. Podrecki, Model, s. 81.

${ }_{44}$ T. Bakalarz, Twórczość pracowników, s. 202; A. Szewc porównuje je do odrębnego wynagrodzenia przysługującego twórcy pracownikowi za pracowniczy projekt wynalazczy, o którym mowa w prawie własności przemysłowej. Zob. A. Szewc, Wynagrodzenie, s. 232.; Tego rodzaju „świadczenie dodatkowe" nie będzie stanowiło wynagrodzenia za pracę (w ścisłym rozumieniu tego pojęcia), zob. 
brzmieniem przepisu łączone z pojęciem „twórca” a nie „pracownik”45. Dlatego wynagrodzenie ma cywilnoprawny, nie pracowniczy charakter i jest swoistą finansową rekompensatą dla twórcy za korzystanie przez instytucję naukową z pierwszeństwa publikacji przed innymi podmiotami ${ }^{46}$. Umowną podstawą wynagrodzenia twórcy jest umowa o wydanie utworu, lecz wynagrodzenie nie jest świadczeniem wzajemnym za prawo publikacji utworu, gdyż uprawnienie instytucji naukowej wynika wprost z przepisu prawa.

Kolejne dwa uprawnienia przysługujące instytucji naukowej to prawo korzystania $\mathrm{z}$ utworu naukowego zawartego $\mathrm{w}$ utworze oraz prawo udostępniania utworu osobom trzecim. Zakres pierwszego uprawnienia nie jest do końca jasny jeśli przyjąć, że pojęciu ustawowemu „materiału zawartego w utworze” należy przypisywać inne znaczenie aniżeli pojęciu „utwór naukowy”. Przepis art. 1 ust. $2^{1}$ PrAut wyraźnie wyłącza spod ochrony prawa autorskiego treści ustaleń naukowych, zatem jej ochrony można poszukiwać wyłącznie w art. 23 K.c., konstruującym ochronę twórczości naukowej jako dobra osobistego ${ }^{47}$. Ponadto od chwili publikacji utworu każda instytucja naukowa może na podstawie dozwolonego użytku przewidzianego w art. 27 ust. 1 PrAut korzystać z rozpowszechnionych utworów w oryginale i w tłumaczeniu na potrzeby zilustrowania treści przekazywanych w celach dydaktycznych lub w celu prowadzenia badań naukowych ${ }^{48}$. Uprawnienie pracodawcy wynikające $z$ art. 14 ust. 2 PrAut dotyczy również utworów nie rozpowszechnionych. Wskazuje się również na inny cel wprowadzenia tej regulacji, gdyż w przeciwieństwie do dozwolonego użytku, który służy rozszerzeniu dostępu do wiedzy, uprawnienie z art. 14 ust. 2 PrAut ma uzasadnienie w stosunkach pracy i ochronie interesów pracodawcy związanych z czerpaniem korzyści z zatrudnienia ${ }^{49}$.

Prawo korzystania $\mathrm{z}$ utworu naukowego zawartego w utworze oraz prawo udostępniania utworu osobom trzecim przysługują instytucji naukowej „bez odrębnego wynagrodzenia", zaś to oznacza, że majątkową rekompensatą twórcy

J. Wratny, Problemy regulacji wynagrodzenia za prace de lege ferenda, PiZS 2013 nr 10, s. 2; wyrok SN z 18.3.2015 r., III PK 110/14.

${ }_{45}$ T. Bakalarz, Twórczość naukowa, s. 46 oraz Twórczość pracowników, s. 200.

${ }^{46}$ D. Sokołowska, Prawo twórcy do wynagrodzenia w prawie autorskim, Poznań 2013, s. 172-173; T. Bakalarz postrzega wynagrodzenie jako rekompensatę za swoistą formę ograniczenia autorskich praw majątkowych. T. Bakalarz, Twórczość pracowników, s. 200.

${ }^{47}$ E. Ferenc-Szydełko, [w:] Ustawa o prawie autorskim i prawach pokrewnych. Komentarz, red. E. Ferenc-Szydełko, Warszawa 2016, s. 168-169;

${ }^{48} \mathrm{Z}$ uwagi na dublowanie się tego uprawnienia dozwolonym użytkiem przyznanym na rzecz instytucji naukowych art. 14 ust. 2 PrAut jest uznawany przez niektórych za zbędny. Zob. W. Machała, Ochrona i eksploatacja utworu naukowego. Zagadnienia wybrane. [w:] Ochrona i zarzadzanie własnością intelektualną $w$ szkołach wyższych $w$ świetle obowiązujących przepisów oraz praktykiwybrane zagadnienia, red. A. Adamczyk, Wynalazczość i ochrona własności intelektualnej, z. 39, Kielce 2015, s. 110.

${ }_{49}$ T. Bakalarz, Twórczość naukowa, s. 172; 
za wynikające $\mathrm{z}$ art. 14 ust. 2 ograniczenia praw autorskich do utworu naukowego jest otrzymane wynagrodzenie za pracę. Uprawnienie instytucji naukowej do korzystania $\mathrm{z}$ materiału naukowego zawartego $\mathrm{w}$ utworze pracowniczym pracownika koresponduje z podstawowym uprawnieniem pracodawcy wynikającym z prawa pracy, a mianowicie prawa korzystania $\mathrm{z}$ rezultatów pracy twórczej w tym celu zatrudnionych pracowników w zamian za zapłatę wynagrodzenia ${ }^{50}$.

W przypadku zatrudniania twórcy przez instytucję naukową na podstawie stosunku pracy podstawą wypłaty wynagrodzenia jest stosunek pracy łączący twórcę utworu $\mathrm{z}$ instytucją naukową. $\mathrm{Z}$ uwagi jednak na regulację szczególną wynikającą $\mathrm{z}$ art. 14 PrAut, na mocy której pracodawca - instytucja naukowa nie nabywa praw autorskich do utworu pracowniczego, wynagrodzenie za pracę nie jest świadczeniem wzajemnym za przeniesienie autorskich praw majątkowych na pracodawcę, ani za udzielenie licencji. Wynagrodzenie stanowi zapłatę za wykonywanie na rzecz pracodawcy pracy, czyli wykonywanie czynności o charakterze rutynowym i twórczym oraz za prawo instytucji do korzystania $\mathrm{z}$ utworu naukowego zawartego $\mathrm{w}$ utworze oraz prawo udostępniania utworu osobom trzecim ${ }^{51}$. Tylko $\mathrm{w}$ przypadku zawarcia $\mathrm{z}$ twórcą dodatkowej umowy dotyczącej wynagrodzenia za skorzystanie przez pracodawcę z prawa pierwszeństwa, wynagrodzenie uzgodnione w tej umowie stanowi rekompensatę za swoiste ustawowe ograniczenie prawa wykonywania praw autorskich.

\section{Umowy cywilnoprawne dotyczące twórczości naukowej i dydaktycznej}

W przypadku gdy twórca nie jest zatrudniany na podstawie stosunku pracy, lecz umowy cywilnoprawnej, sytuacja prawna dotycząca praw i obowiązków stron wygląda zgoła odmiennie. Cywilnoprawna podstawa zatrudniania twórców naukowców częściej jest związana z wykonywaniem przez nich działalności dydaktycznej dotyczącej tworzenia autorskich programów kształcenia dla słuchaczy, przygotowywania materiałów dydaktycznych, prowadzenia wykładów, konwersatoriów i seminariów, egzaminowaniem, nadzorowaniem przygotowywania prac zaliczeniowych i końcowych oraz sprawowaniem opieki promotorskiej. Takie umowy dotyczące wykonywania oznaczonych czynności są uzupełniane o uzgodnienia dotyczące przeniesienia praw autorskich lub udzielenia licencji na korzystanie z utworów powstałych w wyniku wykonywania umowy. Czynności wykonywane na podstawie umowy mają bowiem charakter twórczy. Wynagrodzenie twórców należne z tytułu takiej „mieszanej” umowy, stanowi świadczenie

\footnotetext{
${ }^{50}$ T. Bakalarz, Twórczość naukowa, s. 212; A. Szewc, Wynagrodzenie, s. 228.

${ }^{51}$ W przypadku udostępniania utworu osobom trzecim musi to wynikać również z uzgodnionego przeznaczenia utworu lub z postanowień umowy.
} 
wzajemne za wykonywanie oznaczonych czynności faktycznych, stanowiących kompilację czynności umysłowych oraz rutynowych oraz za dokonanie czynności prawnej, czyli przeniesienie autorskich praw majątkowych na jednostkę naukową lub udzielenie licencji na korzystanie $\mathrm{z}$ utworów powstałych w wyniku wykonywania umowy. Podział procentowy wynagrodzenia na część związaną z wykonywaniem czynności twórczych i część należną z tytułu zadysponowanie prawami autorskimi zależy od woli stron umowy.

W polskiej doktrynie prawa autorskiego dominuje szerokie rozumienie utworu naukowego, obejmujące również utwory dydaktyczne, czyli wytwory służące szeroko rozumianej dydaktyce. Wymienia się m.in. podręczniki, materiały edukacyjne, skrypty czy prezentacje przygotowane w ramach działalności naukowo-dydaktycznej ${ }^{52}$. Nie negując poglądu o naukowym charakterze utworów służących dydaktyce, warto zauważyć, że można wytyczyć granicę pomiędzy utworami naukowymi sensu stricte a utworami dydaktycznymi, przeprowadzając analizę przedmiotu umowy dotyczącej wykonania działalności twórczej. Pomiędzy umową o twórczość dydaktyczną a umową dotyczącą twórczości naukowej sensu stricte można bowiem dostrzec pewne różnice. Gdy przedmiotem umowy jest wykonanie utworu naukowego, do obowiązków twórcy należy zarówno wykonywanie czynności (aktów tworzenia), jak i rozporządzenie prawami autorskimi lub udzielenie licencji do utworu. Wynagrodzenie umowne należne twórcy jest wówczas świadczeniem wzajemnym zarówno za wykonywanie czynności jak i za rozporządzenie prawami autorskimi do utworu. Każdorazowa umowa, której przedmiotem jest twórczość naukowa ma jednorazowy charakter, wynikający $\mathrm{z}$ tego, że utwory naukowe cechuje jednokrotność wykorzystania. Ma to związek z problemem autopowtórzeń szczególnie istotnym w twórczości naukowej ${ }^{53}$. W doktrynie prawa autorskiego oraz prawa pracy wskazuje się, że repetycja własnego wcześniejszego utworu naukowego w całości lub w części, pozbawia w pewnym sensie tę drugą wersję utworu cechy oryginalności ${ }^{54}$. Świadome recypowanie przez twórcę własnej twórczości naukowej do kolejnych publikowanych utworów - w celu powiększenia dorobku naukowego i wprowadzenia w błąd i stworzenia wrażenia wydania dzieła po raz pierwszy - jest kwalifikowane w doktrynie jako czyn stanowiący oszustwo

${ }^{52}$ D. Flisak, Prawo autorskie, s. 205; E. Czarny-Drożdzejko, Wybrane, s. 92; M. PoźniakNiedzielska, G. Tylec, Działalność, s. 36; A.Szewc, Dzieła naukowe i ich status w prawie autorskim, PiP 1997, nr 10, s. 25;

${ }^{53} \mathrm{~W}$ doktrynie używa się pojęcia autoplagiatu, choć na gruncie prawa autorskiego i przyjmowanej definicji plagiatu, termin ten stanowi oksymoron, gdyż nie można być plagiatorem własnego dzieła. J. Sieńczyło-Chlabicz, J. Banasiuk, Pojęcie i istota zjawiska autoplagiatu w twórczości naukowej, PiP 3/2012, s. 11.

${ }^{54}$ S. Stanisławska-Kloc, Plagiat contra autoplagiat, [w:] Spory o własność intelektualna. Księga jubileuszowa dedykowana Profesorom Januszowi Barcie i Ryszardowi Markiewiczowi, Warszawa 2013, s. 1095-1096. 
naukowe ${ }^{55}$. Twórca utworu naukowego nie narusza co prawda niczyich praw autorskich, jednak takie postępowanie może mieć wpływ na ocenę dorobku naukowego. Nie można jednak wykluczyć sytuacji, w której przejmowanie całości lub istotnej części własnego utworu naukowego do kolejnych utworów doprowadzi do naruszenia praw autorskich osób trzecich. Tak będzie w sytuacji gdyby twórca zawarł umowę przeniesienia praw autorskich lub licencji wyłącznej utworu naukowego z jednym podmiotem, a następnie wykorzystał całość lub istotną część tego utworu przy tworzeniu kolejnego utworu, który byłby przedmiotem odrębnej umowy zawieranej z innym podmiotem. Taka praktyka mogłaby doprowadzić do naruszenia praw nabytych przez osobę zawierająca pierwszą umowę, zgodnie z zasadą nemo plus iuris.

W przypadku utworów dydaktycznych problem autopowtórzeń w kolejnych utworach w zasadzie nie stanowi problemu. Utwory dydaktyczne składają się z niechronionych prawem autorskim materiałów (informacji) i opisują stan wiedzy na dany temat. W utworach tych przesłanka twórczości i oryginalności przejawia się w ich formie zewnętrznej (sposobie przedstawienia) oraz doborze, wyborze i zestawieniu materiałów i informacji. Utwory dydaktyczne korzystają zatem z ochrony prawa autorskiego. Ich odmienność od utworów stricte naukowych tkwi jednak w tym, że ich wykorzystanie w pracy twórcy cechuje pewna powtarzalność. Wykład akademicki bywa powtarzany dla różnych słuchaczy i kolejnych roczników studentów, oczywiście z modyfikacjami wymuszonymi jego dostosowaniem na potrzeby konkretnych odbiorców lub zmianą treści naukowych. W przypadku kolejnych aktualizowanych wydań podręczników akademickich, czy skryptów nie można narazić się na zarzut autopowtórzeń, gdyż istotą kolejnego wydania utworu dydaktycznego jest powtórzenie zawartych w nim treści oraz ich uzupełnienie i dostosowanie do aktualnego stanu wiedzy.

Pojawia się jednak pytanie dotyczące przedmiotu kolejnej umowy w sytuacji gdy te same podmioty zawierają kolejną umowę dotyczącą przygotowania (wznowienia) podręcznika akademickiego lub wygłoszenia wykładów z tego samego przedmiotu. Czy twórca utworu dydaktycznego może ponownie przenieść na wydawcę lub instytucję naukową prawa autorskie do utworów (wykładów, podręcznika), o ile taką umowę zawierał już wcześniej? W takiej sytuacji mielibyśmy do czynienia $\mathrm{z}$ ponownym umownym przeniesieniem praw, które przecież przysługują już instytucji naukowej lub wydawcy. Podobnie jest w przypadku wcześniejszego udzielenia licencji, gdyż zgodnie z art. 66 ust. 1 PrAut jeżeli $\mathrm{w}$ umowie nie postanowiono inaczej umowa licencyjna uprawnia do korzysta-

${ }_{55}$ J. Sieńczyło-Chlabicz, J. Banasiuk, Pojęcie, s. 13; D. Skupień, Skutki popetnienia plagiatu lub autoplagiatu przez nauczyciela akademickiego $w$ świetle prawa pracy[w:]Zatrudnienie nauczycieli akademickich red. W. Sanetra, Warszawa 2015, s. 492 i nast. 
nia $\mathrm{z}$ utworu $\mathrm{w}$ okresie pięciu lat i wygasa po upływie tego terminu ${ }^{56}$. Ponowne udzielenie licencji stanowiło by powtórzenie upoważnienia wynikającego $\mathrm{z}$ wcześniejszej umowy. W przypadku zawierania kolejnej umowy pomiędzy twórcą a wydawcą lub instytucją naukową, dotyczącej utworu dydaktycznego możliwe jest zadysponowanie prawami autorskimi lub udzielenie licencji jedynie do tych części utworu, które od czasu zawarcia poprzedniej umowy uległy zmianie, o ile wprowadzane zmiany są efektem pracy twórczej. Dlatego przedmiotem umowy dotyczącej ponownego wydania utworu dydaktycznego lub ponownego przeprowadzenia czynności twórczych związanych z dydaktyką, w większej części będzie twórczość w znaczeniu czynnościowym, aniżeli przedmiotowym.

Można zatem postawić tezę, że w przypadku zawierania przez twórcę pierwszej umowy dotyczącej utworu dydaktycznego, jej przedmiotem jest zarówno dokonywanie czynności twórczych jak i dysponowanie efektem tych czynności - prawami autorskimi do powstałego utworu. Przy kolejnej umowie zawieranej z tym samym kontrahentem, przedmiotem umowy będzie raczej samo wykonywanie czynności twórczych w znaczeniu czynnościowym, w mniejszym natomiast dysponowanie prawami autorskimi, gdyż oświadczenia twórcy o przeniesieniu praw autorskich lub udzieleniu licencji mogą dotyczyć tylko tych części utworu, które nie były objęte wcześniejsza umową. Tym samym proporcja umownego wynagrodzenia pomiędzy wykonaniem oznaczonych czynności faktycznych a umownym zadysponowaniem prawami do utworu dydaktycznego, mimo, że pozostawiona swobodzie stron, w większej części stanowi zapłatę za usługę. $\mathrm{W}$ takim przypadku podział wynagrodzenia umownego powinien być $\mathrm{z}$ korzyścią dla wykonywania czynności twórczych, m.in. wygłoszenia wykładów, czy przygotowania nowej uaktualnionej wersji utworu.

Wątpliwości dotyczące wielokrotnego umownego wykonywania przez twórców twórczości dydaktycznej, powiązanej często z wygłaszaniem wykładów akademickich wynikają również ze specyfiki tej formy przekazu. Wykład akademicki bywa porównywany do artystycznego wykonania ${ }^{57}$, oczywiście $\mathrm{z}$ różnicami wynikającymi z tego, że wykładowi akademickiemu nie przypisuje się cechy artyzmu, gdyż ważniejszym jego elementem jest treść a nie sposób prezentacji (wykonania). Jednakże z uwagi na istotny element wygłoszenia wykładu na żywo (publiczne wykonanie) większe znaczenie ma ta część pracy twórcy, która wiąże się z jego wcześniejszym przygotowaniem a następnie jego wygłoszeniem, a więc z wykonywaniem czynności faktycznych.

56 Oczywiście nie można wykluczyć sytuacji, że w umowie strony przewidziały wydanie oznaczonej ilości egzemplarzy utworu i nakład wynikający z umowy uległ wyczerpaniu.

57 M. Poźniak-Niedzielska, G. Tylec, Działalność s. 37; T. Bakalarz, Twórczość pracowników, s. 148. 


\section{Zakończenie}

Analiza regulacji szczególnej art. 14 PrAut oraz specyfiki wykonywania umowy o twórczość naukową, w tym dydaktyczną, doprowadza do stwierdzenia, że w przeciwieństwie do twórczości niemającej charakteru naukowego, przedmiotem umowy o twórczość naukową są obowiązki twórcy związane wykonywaniem oznaczonej pracy lub świadczeniem usług, niż za dysponowanie prawami autorskimi do utworu. W przypadku wykonywania czynności twórczych w oparciu o stosunek pracy wynika to z regulacji ustawowej zawartej w art. 14 PrAut, która przyznaje pracodawcy twórcy pracowniczego utworu naukowego jedynie trzy uprawnienia do korzystania $\mathrm{z}$ utworu naukowego, pozostawiając twórcy całość praw autorskich. Wynagrodzenie za pracę należne twórcy stanowi zatem zapłatę za samo wykonywanie czynności twórczych. Inaczej będzie tylko w przypadku zawarcia z twórcą - pracownikiem dodatkowej umowy dotyczącej wynagrodzenia za skonsumowanie przez instytucję naukową przysługującego jej na podstawie art. 14 ust. 1 PrAut prawa pierwszego opublikowania utworu naukowego pracownika oraz przy zawarciu z pracodawcą odrębnej umowy, o przeniesieniu autorskich praw majątkowych do utworu lub udzieleniu licencji. Wówczas wynagrodzenie należne twórcy jest związane $\mathrm{z}$ dysponowaniem prawami do utworu.

$\mathrm{W}$ przypadku gdy umowa łącząca twórcę $\mathrm{z}$ innym podmiotem jest umową cywilnoprawną dotyczącą twórczości naukowej, w tym dydaktycznej, to przedmiot takiej umowy będzie w większej części związany ze stroną czynnościową twórczości, aniżeli z jej przedmiotem. Wynika to ze specyfiki pracy naukowo-dydaktycznej, praktyki wielokrotnego wykorzystywania utworów dydaktycznych, zawierania umów dotyczących tego samego lub prawie takiego samego utworu dydaktycznego oraz cechy szczególnej działalności dydaktycznej upodabniającej ją do artystycznych wykonań. To sprawia, że strona czynnościowa twórczości, czyli wykonywanie samych czynności twórczych ma w tych umowach przeważające znaczenie. Jeżeli natomiast przedmiotem umowy cywilnoprawnej jest utwór naukowy sensu stricte, z uwagi na konieczność jego jednokrotnego wykorzystania, przedmiotem umowy będzie twórczość w znaczeniu przedmiotowym i czynnościowym, czyli rozporządzenie prawami autorskimi do utworu lub udzielenie licencji oraz wykonywanie czynności twórczych.

\section{Bibliografia:}

Bakalarz T., Twórczość naukowa pracowników, PS 2010, nr 10, s. 40.

Bakalarz T., Twórczość pracowników naukowych. Regulacja prawna. Warszawa 2015.

Baran K.W. red., Akademickie prawo pracy, komentarz do art. 107-158 oraz 196-201a i 226 ustawyPrawo o szkolnictwie wyższym, Warszawa 2015.

Barta J., R. Markiewicz, Prawo autorskie, Warszawa 2016. 
Barta J., R. Markiewicz, Ustawa o prawie autorskim i prawach pokrewnych, Komentarz wyd V, źródło LEX. Bieganowska M., Ochrona autorsko prawna pracowniczych utworów naukowych, PUG 1998 r., nr 11, s. 23.

Błeszyński J., Prawo autorskie, Warszawa 1985.

Błeszyński J., Prawo autorskie do utworów stworzonych przez pracowników w trakcie wykonywania obowiq̨zków pracowniczych, PUG 1998, nr 11, s. 33.

Bomba K., Od wynagrodzenia za pracę do wynagrodzenia z tytułu zatrudnienia - kilka uwag na temat ewolucji pojęcia wynagrodzenia za pracę, [w:]40 lat Kodeksu pracy, red. Z. Góral, M. Mielczarek, Warszawa 2015, s. 216.

Czarny-Drożdzejko E., Wybrane zagadnienia z zakresu prawa autorskiego w prawie o szkolnictwie wyższym, Przegląd Sądowy, wrzesień 2016, s. 92.

Flisak D. red., Prawo autorskie i prawa pokrewne, Komentarz LEX, Warszawa 2015.

Florek L., Prawo pracy, Warszawa 2015.

Góral Z., O kodeksowym katalogu zasad indywidualnego prawa pracy, Warszawa 2011.

Jaworski L., Podstawa prawna świadczenia twórczości przez pracownika w świetle art. 12 PrAut. MP 6/2005r, s. 295.

Kędzierska-Cieślak K., Pierwszeństwo instytucji naukowej do opublikowania utworu jej pracownika, PIP 1996, z 8-9, s. 83.

Kuczyński T., Twórczość autorska i wynalazcza jako kategoria prawa pracy. Wybrane zagadnienia, PiZS 1998, nr 3, s. 11.

Machała W., Ochrona i eksploatacja utworu naukowego. Zagadnienia wybrane, [w:]Ochrona i zarzqdzanie własnościq intelektualnq w szkołach wyższych w świetle obowiq̨zujących przepisów oraz praktyki - wybrane zagadnienia, red. A. Adamczyk, Wynalazczość i ochrona własności intelektualnej, z. 39, Kielce 2015, s. 109.

Niewęgłowski A., Wyniki prac badawczych w obrocie cywilnoprawnym, Warszawa 2010.

Nowak M., Wynagrodzenie za pracę, Warszawa 2014.

Ogiegło L., Pojęcie usługi i umów o świadczenie usług w ujęciu kodeksu cywilnego, SIS 1979, t. V, s.140.

Piątkowski J., Aksjologiczne i normatywne podstawy prawa stosunku pracy, Toruń 2013.

Podrecki P., Model ochrony praw własności intelektualnej w szkołach wyższych i instytucjach naukowo-badawczych oparty na przepisach prawa autorskiego, [w:] Europejskie regulacje $w$ dziedzinie własności przemysłowej- nowe wyzwania, red. A. Adamczyk, Wynalazczość i ochrona własności intelektualnej, z. 28, Kielce 2004, s. 81.

Poźniak-Niedzielska M., G. Tylec, Działalność naukowo-dydaktyczna na wyższej uczelni w świetle prawa autorskiego, PiP 5/2009, s. 36.

Sieńczyło-Chlabicz J., J. Banasiuk, Pojęcie i istota zjawiska autoplagiatu w twórczości naukowej, PiP 3/2012, s. 11.

Skąpski M., Charakter prawny studiów doktoranckich, PiP 1998, nr 2, s. 70.

Skąpski M., Ochronna funkcja prawa pracy w gospodarce rynkowej, Warszawa 2006.

Skupień D., Skutki popełnienia plagiatu lub autoplagiatu przez nauczyciela akademickiego w świetle prawa pracy [w:] Zatrudnienie nauczycieli akademickich red. W. Sanetra, Warszawa 2015.

Sokołowska D., Prawo twórcy do wynagrodzenia w prawie autorskim, Poznań 2013

Stanisławska-Kloc S., Plagiat contra autoplagiat, [w:] Spory o własność intelektualną. Księga jubileuszowa dedykowana Profesorom Januszowi Barcie i Ryszardowi Markiewiczowi, Warszawa 2013, s. 1095.

Stec P., Uczelnia jako podmiot praw na dobrach niematerialnych, PiP 1/2008, s. 57.

Stelina J., Ocena kodeksu pracy z punktu widzenia wybranych jego regulacji, [w:] 40 lat Kodeksu pracy, red. Z. Góral, M. Mielczarek, Warszawa 2015, s. 90.

Stelina J., red. Prawo pracy, Warszawa 2016.

Szewc A., Dzieła naukowe i ich status w prawie autorskim, PiP 1997 r., nr 10, s. 23.

Szewc A., Wynagrodzenie twórców i wykonawców w prawie autorskim i wynalazczym, Sopot 1999. 
System Prawa Prywatnego, Prawo autorskie, tom 13, red. J. Barta, Warszawa 2017.

Targosz T., Prawa pracodawcy do utworów pracowniczych - art. 12 pr. Aut. Jako reguła przyporządkowania praw autorskich w stosunku pracy, [w:] Spory o własność intelektualnq, Księga jubileuszowa dedykowana Profesorom Januszowi Barcie i Ryszardowi Markiewiczowi, red. A. Matlak, S. Stanisławska-Kloc, Warszawa 2013, s. 1287.

Ustawa o prawie autorskim i prawach pokrewnych. Komentarz, red. E. Ferenc-Szydełko, Warszawa 2016. Wratny J., Problemy regulacji wynagrodzenia za pracę de lege ferenda, PiZS 2013 nr 10, s. 2.

Wronkowska S., Podstawowe pojęcia prawa i prawoznawstwa, Poznań 2005.

\section{Streszczenie}

Cechą szczególną pracy twórczej jest jej faktyczny charakter. Jej zwieńczeniem jest powstanie utworu prawa autorskiego - dobra prawnie chronionego, które z mocy samego prawa w momencie jego ustalenia, staje się przedmiotem prawa. Stosunek prawny wykreowany umową o wykonywanie pracy twórczej jest dość złożony. W pojęciu twórczości można bowiem rozróżnić dwa podstawowe znaczenia: czynnościowe i przedmiotowe. Jeżeli przedmiotem umowy jest wykonywanie twórczości naukowej (również dydaktycznej) uwzględnić należy również regulacje szczególne dotyczące nabywania praw do utworów naukowych przez instytucję naukową oraz cechy szczególne pracy o charakterze naukowym i dydaktycznym. Struktura świadczenia umownego wynikającego z zawarcia umowy dotyczącej twórczości naukowo-dydaktycznej, wskazuje, że przedmiotem takiej umowy w większym zakresie jest twórczość w znaczeniu czynnościowym, aniżeli przedmiotowym. Analiza regulacji szczególnej art. 14 prawa autorskiego oraz specyfiki wykonywania umowy o twórczość naukową, w tym dydaktyczną, doprowadza do stwierdzenia, że w przeciwieństwie do twórczości niemającej charakteru naukowego, przedmiotem umowy o twórczość naukową są obowiązki twórcy związane wykonywaniem oznaczonej pracy lub świadczeniem usług, niż za dysponowanie prawami autorskimi do utworu.

Słowa kluczowe: twórczość naukowa, utwór naukowy, praca twórcza, wynagrodzenie umowne.

\section{Subject matter of the obligation in the contract of scientific works}

\section{Abstract:}

The characteristic feature of creative work is its actual character. Its culmination is the creation of a copyrighted work - a legally protected good which, by the law itself, at the time of its establishment, becomes the subject of law. The legal relationship created by the contract for the performance of creative work is quite complex. In the concept of creativity one can distinguish two basic meanings: functional and material. Where the subject matter of the contract is the performance of scientific (as well as didactic) works, account should also be taken of the special rules governing the acquisition of rights to scientific works by a scientific institution and the special characteristics of scientific and didactic work. The structure of the contractual performance resulting from the conclusion of an agreement on scientific and didactic works indicates that the subject matter of such a contract is, to a greater extent, works in the functional sense rather than material. Analysis of the special regulation of Article 14 of the copyright law and the specific nature of the performance of the contract of scientific works, including didactics, leads to the conclusion that, unlike non-scientific works, the subject matter of a scientific works contract is the creator's obligation related to the performance of a designated work or to the provision of services, rather than having the copyright to the work.

Keywords: scientific works, scientific work, creative work, contractual remuneration. 